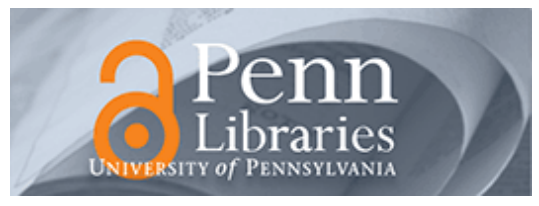

University of Pennsylvania

ScholarlyCommons

Marketing Papers

Wharton Faculty Research

$3-2010$

\title{
Predicting Elections from Biographical Information about Candidates: A Test of the Index Method
}

\section{J. Scott Armstrong}

University of Pennsylvania, armstrong@wharton.upenn.edu

Andreas Graefe

Karlsruhe Institute of Technology

Follow this and additional works at: https://repository.upenn.edu/marketing_papers

Part of the Business Commons

\section{Recommended Citation}

Armstrong, J. S., \& Graefe, A. (2010). Predicting Elections from Biographical Information about Candidates: A Test of the Index Method. Retrieved from https://repository.upenn.edu/marketing_papers/ 162

Suggested Citation:

Armstrong, J.S. and Graefe, A. (2011). Predicting Elections from Biographical Information about Candidates: A Test of the Index Method. Journal of Business Research. Vol. 64(7). p. 699-706.

Publisher URL: http://dx.doi.org/10.1016/j.jbusres.2010.08.005

This paper is posted at ScholarlyCommons. https://repository.upenn.edu/marketing_papers/162

For more information, please contact repository@pobox.upenn.edu. 


\title{
Predicting Elections from Biographical Information about Candidates: A Test of the Index Method
}

\author{
Abstract \\ We used 59 biographical variables to create a "bio-index" for forecasting U.S. presidential elections. The \\ bio-index method counts the number of variables for which a candidate rates favourably, and the forecast \\ is that the candidate with the highest score would win the popular vote. The bio-index relies on different \\ information and includes more variables than traditional econometric election forecasting models. The \\ method can be used in combination with simple linear regression to estimate a relationship between the \\ index score of the candidate of the incumbent party and his share of the popular vote. The study tested \\ the model for the 29 U.S. presidential elections from 1896 to 2008 . The model"s forecasts, calculated by \\ cross-validation, correctly predicted the popular vote winner for 27 of the 29 elections; this performance \\ compares favourably to forecasts from polls (15 out of 19), prediction markets (22 out of 26), and three \\ econometric models (12 to 13 out of 15 to 16). Out-of-sample forecasts of the two-party popular vote for \\ the four elections from 1996 to 2008 yielded a forecast error almost as low as the best of seven \\ econometric models. The model can help parties to select the candidates running for office, and it can \\ help to improve on the accuracy of election forecasting, especially for longer-term forecasts.

\section{Disciplines \\ Business}

\section{Comments} \\ Suggested Citation: \\ Armstrong, J.S. and Graefe, A. (2011). Predicting Elections from Biographical Information about \\ Candidates: A Test of the Index Method. Journal of Business Research. Vol. 64(7). p. 699-706. \\ Publisher URL: http://dx.doi.org/10.1016/j.jbusres.2010.08.005
}




\section{Predicting Elections from Biographical Information about Candidates: A test of the index method}

Journal of Business Research (forthcoming subject to further revisions)

J. Scott Armstrong, The Wharton School, University of Pennsylvania

Andreas Graefe, Karlsruhe Institute of Technology, Germany

March 2010

John Antonakis, Kay A. Armstrong, Roy Batchelor, Alfred Cuzán, Ray Fair, Dan Goldstein, Kesten C. Green, Robin Hogarth, Randall Jones, Frank L. Schmidt, Dean K. Simonton and Christopher Wlezien provided helpful comments. Suggestions were obtained from our talks at the 2009 International Symposium on Forecasting in Hong Kong and the Symposium on Leadership and Individual Differences in Lausanne (Nov. 2009). We asked authors of key papers whether we cited their work correctly: Thanks to Rudy Andeweg, Alice Eagly, Timothy Judge, John Krantz, Andrew Leigh, James Nelson, Panu Poutvaara and Burt Pryor for responding. Andrew Dalzell, Ishika Das, Rui Du, Max Feldman, Rong Fu, Greg Lafata and Martin Yu helped with collecting data. Send correspondence to J. Scott Armstrong, The Wharton School, University of Pennsylvania, Philadelphia, PA (armstrong@ wharton.upenn.edu). 


\begin{abstract}
We used 59 biographical variables to create a "bio-index" for forecasting U.S. presidential elections. The bio-index method counts the number of variables for which a candidate rates favourably, and the forecast is that the candidate with the highest score would win the popular vote. The bio-index relies on different information and includes more variables than traditional econometric election forecasting models. The method can be used in combination with simple linear regression to estimate a relationship between the index score of the candidate of the incumbent party and his share of the popular vote. The study tested the model for the 29 U.S. presidential elections from 1896 to 2008 . The model's forecasts, calculated by cross-validation, correctly predicted the popular vote winner for 27 of the 29 elections; this performance compares favourably to forecasts from polls (15 out of 19), prediction markets (22 out of 26), and three econometric models (12 to 13 out of 15 to 16). Out-of-sample forecasts of the two-party popular vote for the four elections from 1996 to 2008 yielded a forecast error almost as low as the best of seven econometric models. The model can help parties to select the candidates running for office, and it can help to improve on the accuracy of election forecasting, especially for longer-term forecasts.
\end{abstract}

Keywords: econometric model, election forecasts, forecast accuracy, index model, political forecasting political marketing, unit-weighting 
This study examines the extent to which knowledge of biographical and demographic information about candidates allows for predicting the outcomes of U.S. presidential elections. Such an approach might prove useful for the selection of candidates as well as to improve the accuracy of election forecasts, especially long-term forecasts.

\section{The index method}

To address this problem, the data are analyzed with the index method. The index method asks analysts to prepare a list of key variables and to specify from prior evidence whether the variables are favorable $(+1)$, unfavorable $(-1)$, or indeterminate $(0)$ in their influence on a certain outcome. Alternatively, the scoring can be 1 for a positive position and zero otherwise. Then, the analysts simply add the scores and use the total to calculate the forecast.

Researchers have used the index method for various types of forecasting problems. For example, Burgess (1939) applied the index method to predict the success of paroling individuals from prison. For each of 25 factors, the author rated whether the factor is "favorable" $(+1)$ or "unfavorable" (0) and calculated an index score to determine the chance of successful parole.

The beginnings of the index method trace back to Benjamin Franklin. On September 19, 1972, Franklin wrote a letter to his friend Joseph Priestly, in which he described 'a method of deciding doubtful matters' that works similar to the index method (in Sparks, 1856, p.20).

Unlike Franklin's method, this study does not give consideration to the magnitudes of the ratings or to the effect size of the variables. While these issues can be addressed, prior research suggests that such factors have little impact on accuracy. Based on their analysis of linear models for four decision-making problems, Dawes and Corrigan (1974) concluded that the key to accuracy for non-experimental data in the social sciences is to select the proper variables and to assess the directions of effects. 


\section{Conditions for the index method}

In using unit or equal weights, the analyst assesses the directional influence of a variable

on the outcome by drawing upon evidence from prior research or experts' domain knowledge. If little knowledge exists, the analyst should question the relevance of including a variable in the model. Thus, the index method is particularly valuable in situations with good prior domain knowledge.

Analysts can incorporate an unlimited number of variables in an index model and can use whichever variables are relevant to the event being forecast. The ability to use all cumulative knowledge in a domain is an important advantage of the index method. One might call them "knowledge models."

In sum, the index method is valuable in situations involving many causal variables and good prior knowledge about the influence of the variables on the outcome. In contrast to the research on equal weights, the index method goes beyond a given set of data and enables the analyst to use all available knowledge.

Few researchers appear to be aware of the value of the index method. Prior to a talk at the 2009 International Symposium on Forecasting, the authors conducted a small survey to ask researchers in the forecasting field for their expectations about the relative performance of the index method, multiple regression, and step-wise regression in situations with a large number of variables and few observations. On average, the 13 experts who rated themselves as high on 'expertise with forecasting methods' expected regression to yield the most accurate results, followed by the index method. 


\section{Use of the index method in election forecasting}

Given that the number of potential variables is large and that a substantial body of knowledge exists about how certain factors influence voting, forecasting of U.S. presidential elections lends itself to the use of index models. In addition, data in this situation is limited to about 25 elections at most. Dana and Dawes (2004) analyze relative performance of multiple regression and unit weighting for five real social science datasets and a large number of synthetic datasets. The authors conclude that regression should not be used unless sample size is larger than 100 observations per predictor.

Cuzán and Bundrick (2009) apply an equal-weighting approach to three regression models: Fair's equation (Fair, 1978) and two variations of the fiscal model (Cuzán and Heggen, 1984). For the 23 elections from 1916 to 2004, the equal weighting scheme outperformed two of the three regression models - and performed equally to the third - when making out-of-sample predictions. For the full sample of 32 elections from 1880 to 2004, equal weighting yielded a lower mean absolute error than all three regression models.

Lichtman (2006) was the first to use the index method to forecast U.S. presidential election winners. His model, which uses 13 variables, provided correct forecasts retrospectively for all of 31 elections and prospectively for all of the last 7 elections. No econometric model achieved this level of accuracy in picking the winner of the popular vote. The Lichtman model uses the same variables for all elections and is based only on the judgments of a single rater, Lichtman.

Armstrong and Cuzán (2006) use simple linear regression to transform Lichtman's model into a quantitative model and to compare the model's ex ante forecasts to forecasts from three traditional regression models for the six U.S. presidential elections from 1984 to 2004. The transformed Lichtman model performed well and yielded forecast errors that were competitive to 
those of three established regression models. For the 2008 election, the forecast from Lichtman's model-issued in August 2007, more than a year before Election Day missed the actual outcome by only 0.3 percentage points — and was again more accurate than the out-of-sample forecasts derived from the same three models.

\section{Biographical index}

Table 1 provides an overview of the 59 variables that were used to compose a biographical index model. Based on perceived wisdom and findings from prior research, these variables were expected to have an influence on election outcomes. Details on these variables, along with sources, are provided in Appendix 1.

Table 1 about here

One example of a biographical variable that has value in predicting election outcomes is the perceived facial competence of candidates. Todorov, Mandisodza, Goren and Hall (2005) presented 31 subjects with pictures of candidates running in U.S. House and Senate elections. Based on one-second exposures, the subjects rated each candidate's competence. Subjects who recognized a candidate were excluded. For the three Senate elections from 2000 to 2004, the most competent-looking candidates won $71 \%$ of the 95 races. For the two House elections in 2002 and 2004, the most competent-looking candidates won $67 \%$ of the 600 races in their sample. In a similar study, Antonakis and Dalgas (2009) asked 684 university students and 2,814 children in Switzerland to rate pairs of black and white photos of faces of candidates in the 2002 French parliamentary election. In both samples, the candidates that achieved higher ratings on facial 
competence won in $72 \%$ of the elections. Similarly, Armstrong, Green, Jones and Wright (2010) found facial competence to be predictive for the outcome of the 2008 U.S. presidential primaries. A few of the variables are fixed (e.g., height) while others are subject to change. For an example of variables that can be changed, consider the use of eyeglasses. A lab experiment found that people wearing eyeglasses are perceived to be more industrious, dependable, and honest (Thornton, 1944). Findings from another lab experiment show that eyeglasses can enhance an individual's perceived authority (Bartolini, Kresge, McLennan, Windham, Buhr and Pryor, 1988).

People might not consciously evaluate all relevant traits when selecting their leaders. An example is birth order. Newman and Taylor (1994) analyze samples of 45 male U.S. Governors and 24 Australian prime ministers. Compared to the population at large, the politicians in both samples were more likely to be first-born and less likely to be middle-born. Similarly, Andeweg and Van Den Berg (2003) show that single children were overrepresented among a sample of almost 1,200 Dutch politicians, whereas middle-children were underrepresented. Another example is the experience of traumatic or adverse events like the early loss of a parent. Simonton (1999) reports on various studies that found that geniuses from various fields are more likely to be orphaned than the remainder of the population. For example, one of these studies found that 15 of 24 British prime ministers were orphans.

In sum, empirical research supports the relevance of numerous biographical traits for the emergence of leaders. Given the large number of variables, the index method is an appropriate choice for predicting election winners based on biographical traits. 


\section{Coding}

Each variable was coded for whether the variable has a positive or negative influence on votes. There are two types of variables: (1) Yes / no variables indicate whether a candidate has a certain characteristic or not. Examples include whether a candidate is a single child, is married, or graduated from college. (2) Comparative variables incorporate information about the relative value of the variable for the candidates that run against each other in a particular election. Here, the candidate who achieves a more favorable value on a variable is assigned a score of 1 and 0 otherwise. Examples include candidates' height, intelligence, or attractiveness. Thus, the taller candidate would score a 1 , and the shorter a 0 .

Two independent coders rated the candidates. If these coders disagreed, a third coder

made the final decision. (The final coding is available online at tinyurl.com/pollybio-coding.) The sum of variable values for each candidate in a particular election determines the candidate's bioindex score (B).

\section{Data}

Biographical data were collected on the candidates of the two major parties that ran for office in the 29 elections from 1896 to 2008. All data refer to the candidate's biography at the time of the respective election campaign, and were obtained from candidate's biographies, fact books, encyclopedias and earlier studies. For more information see Appendix 1.

\section{Predictive performance of the bio-index}

The bio-index incorporates two ways for predicting the outcome of elections: (1) a simple heuristic to predict the election winner and (2) a quantitative model to predict the popular twoparty vote shares of the candidates running for office. 


\section{Heuristic based approach}

To apply the heuristic, the analyst has to assess the direction for how a variable will influence the election outcome, assign values to the candidates, and then sum the values to calculate the index scores. The candidate with the higher bio-index score (B) is predicted as the winner of the popular vote.

Table 2 shows the candidates' index scores in each election year. For the 29 elections, the heuristic correctly predicted the winner 27 times and was incorrect twice. Thus, the proportion of correct forecasts (i.e., hit rate) is 0.93. The heuristic did not predict Bill Clinton to succeed George Bush in 1992, and, in 1976, the forecast wrongly predicted Gerald Ford to win against Jimmy Carter.

Table 2 about here

\section{Bio-index heuristic versus polls}

Campaign - or trial heat - polls reveal voter support for candidates in an election.

Although polls are only assessments of current opinion or snapshots, their results are routinely interpreted as forecasts and projected to Election Day. For example, the trial-heat forecasting model by Campbell (1996) uses the economic growth rate and Gallup trial-heat polls as predictor variables. However, polls conducted early in the campaign are commonly seen as unreliable, which is why Campbell adjusts their results according to the historical relationship between the vote and the polls.

This study compares the performance of the bio-index to the predicted two-party vote shares from the final pre-election Gallup poll. The Gallup polling data for the 18 elections from 
1936 to 2004 are published in the Appendix in Snowberg, Wolfers, and Zitzewitz (2007). For the 2008 election, the final pre-election poll was obtained from gallup.com. The hit rate, shown in Table 3 , is the proportion of forecasts that correctly determined the election winner. Four times out of the last 19 elections, the final pre-election Gallup poll predicted the wrong candidate to win the election and thus yielded a hit rate of 0.79 . By comparison, the bio-index heuristic failed twice for the same sample of 19 elections (a hit rate of 0.89 ).

Table 3 about here

Bio-index heuristic versus prediction markets

Prediction markets to forecast election outcomes have been popular since the late 19th century. Rhode and Strumpf (2004, p. 127) study historical betting markets that existed for the 15 presidential elections from 1884 through 1940 and concluded that these markets "did a remarkable job forecasting elections in an era before scientific polling”. Since 1988, the Iowa Electronic Market (IEM), an internet-based futures market in which participants trade contracts on the outcome of future events, has provided forecasts of U.S. presidential election outcomes. Berg, Nelson and Rietz (2008) compared 964 polls to IEM forecasts for the five presidential elections from 1988 to 2004 and found that IEM forecasts were closer to the actual election results $74 \%$ of the time. However, this advantage disappeared when compared to combined and damped polls (Erikson and Wlezien, 2008).

The present study compares the bio-index to prediction market prices from the last day prior to Election Day. Prediction market data were available for 26 of the last 29 elections. For the period from 1896 to 1960, forecasts were taken from the historical Wall Street Curb markets 
as described in Rhode and Strumpf (2004). For the four elections from 1976 to 1988, the study analyzes betting odds from British bookmakers. Both data sets are published in the Appendix to Snowberg et al. (2007). For the last five elections from 1992 to 2008, the data include publicly available prices from the IEM. (For the three elections from 1964 to 1972, no prediction market was available.) The three datasets are slightly different. While the Wall Street Curb markets and the bookmakers predicted the Electoral College winner, the IEM provided a forecast of the popular vote winner. Nonetheless, each market provided winner-take-all prices. This price reflects the probability with which the market expects a candidate to win. For example, a market price of $\$ 80$ indicates an $80 \%$ chance of winning. Thus, if the price of a candidate exceeds $50 \%$, the market predicts this candidate to win the election. The results are shown in Table 3 . The prediction markets achieved 22 (out of 26) correct predictions, which corresponds to a hit rate of 0.85 , compared to 0.92 for the bio-index heuristic for the same elections.

\section{Bio-index heuristic versus econometric models}

Table 3 shows the hit rates of three well-established econometric models for which out-of-sample forecasts for early elections are available. The forecasts from these models were calculated by N1 cross-validation. This means that the analyst used N-1 observations from the dataset to build the model and then made a forecast for the one remaining election. Abramowitz (1996) and Campbell (1996) publish cross-validated forecasts from 1948; Wlezien and Erikson's forecasts are available from 1952 (Wlezien, 2001). For the three most recent elections, ex ante forecasts, published before the actual Election Day, are available from the authors' respective publications in the elections symposia in PS: Political Science and Politics, 34(1), 37(4), and 41(4). In predicting 16 elections, Abramowitz's model failed four times, yielding a hit rate of 0.75 . Both Campbell (16 elections) and Wlezien and Erikson (15 elections) missed the correct winner three 
times and achieve hit rates of 0.81 and 0.80 , respectively. Compared to each of the three models, the bio-index heuristic yielded a higher hit rate, as shown in the last column of Table 3.

In sum, the forecasts from the bio-index heuristic — made in January of the respective election year - yielded a higher hit rate than forecasts from polls, prediction markets, and econometric models.

\section{Predicting the vote share}

Bio-indexes can also be used to build a model for forecasting the incumbent party candidate's percentage of the two-party vote. The relative bio-index score $(\mathrm{P})$ of the candidate of the incumbent party represents the predictor variable. $\mathrm{P}$ is the percentage of variables that favored the candidate of the incumbent party and is defined as:

$$
\mathrm{P}=\left[\mathrm{B}_{\text {Incumbent }} /\left(\mathrm{B}_{\text {Incumbent }}+\mathrm{B}_{\text {Challenger }}\right)\right]^{* 100}
$$

We estimated a simple regression model using $\mathrm{V}$, the actual two-party vote share received by the candidate of the incumbent party as the dependent variable. For the period from 1896 to 2008, this yielded the following vote equation:

$$
\mathrm{V}=18.0+0.65 * \mathrm{P}
$$

Thus, the model predicts that an incumbent would start with $18 \%$ of the vote, plus a share depending on $\mathrm{P}$. If the percentage of biographical variables favoring the incumbent goes up by 10 percentage points, the incumbent's vote share will go up by $6.5 \%$.

\section{Accuracy of the bio-index model}

Table 4 shows out-of-sample vote-share forecasts of the bio-index model, calculated by N-1 cross-validation. As with the heuristic-based approach, the model-based approach correctly 
predicted 27 elections and failed for the elections in 1976 and 1992. Over all 29 elections, the mean absolute error (MAE) of the bio-index model was 4.6 percentage points.

Table 4 about here

The bio-index model's forecasts of the winner were identical to those for the bio-index heuristic. Thus, the model's hit rate outperformed the polls, prediction markets, and econometric models.

\section{Bio-index model versus econometric models}

Because the bio-index model provides vote-share forecasts, the model's predictions can be compared to forecasts from econometric models. Given that the data are more extensive and more accurate for recent elections (remember that the econometric models suffer from small sample sizes), the comparison focuses on pure ex ante forecasts for the most recent four elections. That is, only data from elections prior to the respective election year were used for building the model. For example, to predict the 2008 election, data on the 28 elections from 1896 to 2004 were used; for the 2004 election, data on the 27 elections from 1896 to 2000 were used, and so on.

Table 5 shows such ex ante forecasts from the bio-index model and seven well-established econometric models. Most of these forecasts were published in American Politics Quarterly 24(4) and PS: Political Science and Politics, 34(1), 37(4), and 41(4). Fair reports the forecasts of his model on his website (fairmodel.econ.yale.edu). For an overview of the predictor variables used in most of the models, see Jones and Cuzán (2008).

The bio-index model performed well compared to the seven econometric models. Even though the bio-index model made its forecasts many months before most other models, the model yielded a MAE almost as low as that yielded by the most accurate econometric model. Since the 
bio-indexes of candidates basically never change during an election campaign, the results would be identical if one would compare forecasts made at around the same time.

Table 5 about here

\section{Discussion}

The bio-index model relies on prior studies and domain knowledge for choosing variables. Because the index method allows for an unlimited number of variables and does not weight variables, the analyst can use different variables when forecasting new events. For example, for predicting different-gender races, one might want to exclude variables that are only relevant for same-gender races (e.g., height and weight). Furthermore, the index method allows for adding variables once new information becomes available, for example, if a new variable is discovered that is not yet incorporated in the model (e.g., if a candidate was awarded the Nobel Peace Prize). This flexibility is an important advantage as the index method allows for using all cumulative knowledge in a domain.

\section{When is a bio-index most effective?}

In general, election forecasters consider open-seat elections (i.e., without an incumbent in the race) harder to forecast. For the elections from 1868 to 2004, Campbell (2008) compares the outcomes of the 13 open-seat elections to the 22 elections with an incumbent in the race. He finds that open-seat elections are more often near dead heats than elections with an incumbent running. Also, out of the 11 elections in his sample that were decided by a landslide, only two were openseat. 
A closer look at the performance of the three econometric models listed in Table 3 supports the speculation that traditional election forecasting models have difficulties in predicting open-seat elections. All three models failed to correctly predict the winner of the elections in 1960 and 1968; Campbell's model also missed the winner in 2008. Each of these elections was an open-seat election. By comparison, as shown in Table 4, the bio-index model correctly predicted the winner for each of the ten open-seat elections in our sample. Although drawing on a small sample, the results suggest that the bio-index model is helpful for predicting the outcome of open-seat elections.

\section{Bio-indexes as nomination helper}

The bio-index method can issue its forecast as soon as the candidates are known - or even before, conditional on who might run for office. Thus, bio-indexes can advise candidates whether they should enter the race and can help parties in nominating their candidates. Parties should select the candidate who achieves a high index score-possibly conditional to a specific opponent.

Bio-indexes are simple to use and easy to understand. For predicting the winner, a simple heuristic can be used that does not require information from previous elections. Bio-indexes can also be used in combination with regression to allow for quantitative vote predictions.

The index model would also be useful for many other problems involving a large number of variables, small data sets, and a good knowledge base. Examples include selection problems such as predicting which CEO a company should hire, where to locate a retail store, which product to develop, or whom to marry.

\section{Conclusion}

The present study applies the index method to the 29 U.S. presidential elections from 1896 to 2008 and provides forecasts based on biographic information about candidates. For 27 of the 29 
elections, the bio-index heuristic and the bio-index model each correctly predicted the popular vote winner, a performance that is superior to polls, prediction markets, and three econometric models. In addition, the model's ex ante forecasts of the popular vote for the four elections from 1996 to 2008 yielded a forecast error almost as low as the best of seven econometric models.

In using a different method and drawing on different information than traditional election forecasting models, the bio-index model can contribute to forecasting accuracy. Bio-indexes are simple to use, easy to understand, and can help political parties in nominating candidates running for office. 


\section{References}

Abramowitz Alan I. Bill and Al's excellent adventure: Forecasting the 1996 presidential election. American Politics Research 1996; 24(4): 434-442.

Andeweg Rudy B., Van Den Berg Steef B. Linking birth order to political leadership: The impact of parents or sibling interaction? Political Psychology 2003; 24(3): 605-623.

Antonakis John, Dalgas Olaf. Predicting elections: Child's play! Science 2009; 323(5918): 1183.

Armstrong Scott J., Cuzán Alfred G. Index methods for forecasting: An application to the American presidential elections. Foresight 2006; Issue 3 (February): 10-13.

Armstrong Scott J., Green Kesten C., Jones Randall J., Wright Malcolm (2010). Predicting elections from politicians' faces. International Journal of Public Opinion Research (forthcoming).

Bartolini Tony, Kresge Jill, McLennan Misty, Windham Becky, Buhr Thomas A., Pryor Burt. Perceptions of personal characteristics of men and women under three conditions of eyewear. Perceptual and Motor Skills 1988; 67(December): 779-782.

Berg Joyce E., Nelson Forrest D., Rietz Thomas A. Prediction market accuracy in the long run. International Journal of Forecasting 2008; 24(2): 285-300.

Burgess EW. Predicting success or failure in marriage. New York: Prentice-Hall, 1939.

Campbell James E. Polls and votes: The trial-heat presidential election forecasting model, certainty, and political campaigns. American Politics Research 1996; 24(4): 408-443. 
Campbell James E. The trial-heat forecast of the 2008 presidential vote: Performance and value considerations in an open-seat election. PS: Political Science \& Politics 2008; 41(4): 697701.

Cuzán Alfred G., Bundrick Charles M. Predicting presidential elections with equally-weighted regressors in Fair's Equation and the Fiscal Model. Political Analysis 2009; 17(3): 333340.

Cuzán Alfred G., Heggen Richard J. A fiscal model of presidential elections in the United States: 1880-1980. Presidential Studies Quarterly 1984; 14(1): 98-108.

Dana Jason, Dawes Robyn M. The superiority of simple alternatives to regression for social science predictions. Journal of Educational and Behavioral Statistics 2004; 29(3): 317331.

Dawes Robyn M., Corrigan Bernard. Linear models in decision making. Psychological Bulletin 1974; 81(2): 95-106.

Erikson Robert S., Wlezien Christopher. Are political markets really superior to polls as election predictors? Public Opinion Quarterly 2008; 72(2): 190-215.

Fair Ray C. The effect of economic events on votes for president. Review of Economics and Statistics 1978; 60(2): 159-173.

Jones Randall J., Cuzán Alfred G. Forecasting U.S. presidential elections: A brief review. Foresight 2008; Issue 10(Summer): 29-34.

Lichtman Allan J. The keys to the white house: Forecast for 2008. Foresight 2006; Issue 3 (February): 5-9. 
Newman Joan, Taylor Alan. Family training for political leadership: Birth order of United States state governors and Australian prime ministers. Political Psychology 1994; 15(3): 435442.

Rhode Paul W., Strumpf Koleman S. Historic presidential betting markets. Journal of Economic Perspectives 2004; 18(2): 127-142.

Simonton DK. Origins of genius. Oxford: Oxford University Press, 1999.

Snowberg Erik, Wolfers Justin, Zitzewitz Eric. Partisan impacts on the economy: Evidence from prediction markets and close elections. Quarterly Journal of Economics 2007; 122(2): 807-829.

Sparks J. The works of Benjamin Franklin. Boston, MA: Whittemore, Niles, and Hall, 1856.

Thornton G. R. The effect of wearing glasses upon judgments of personality traits of persons seen briefly. Journal of Applied Psychology 1944; 28(3): 203-207.

Todorov Alexander, Mandisodza Anesu N., Goren Amir, Hall Crystal C. Inferences of Competence from Faces Predict Election Outcomes. Science 2005; 308(5728): 16231626.

Wlezien Christopher. On forecasting the presidential vote. PS: Political Science and Politics 2001; 34(1): 24-31. 
Table 1: Bio-index variables

\begin{tabular}{|c|c|c|c|}
\hline No. & Variable & No. & Variable \\
\hline 1 & Adopted children & 31 & Vice President \\
\hline 2 & Ancestry & 32 & Disability \\
\hline 3 & Children & 33 & Disease survivor \\
\hline 4 & Divorce & 34 & Chronic illness \\
\hline 5 & Father (political office) & 35 & Loss of children \\
\hline 6 & First born & 36 & Loss of sibling \\
\hline 7 & Single child & 37 & Loss of spouse \\
\hline 8 & Marriage & 38 & Orphanhood \\
\hline 9 & College & 39 & Age \\
\hline 10 & College graduate & 40 & Athlete \\
\hline 11 & Law degree & 41 & Book author \\
\hline 12 & Master's degree & 42 & Celebrity \\
\hline 13 & $\mathrm{PhD}$ & 43 & Facial hair \\
\hline 14 & Professor & 44 & Glasses \\
\hline 15 & Phi beta kappa & 45 & Hair \\
\hline 16 & Prestigious college & 46 & Military experience \\
\hline 17 & U.S. Naval / Military Academy & 47 & Military honors \\
\hline 18 & Attorney General & 48 & Gender \\
\hline 19 & City major & 49 & Facial competence \\
\hline 20 & Election defeat & 50 & First name \\
\hline 21 & Governor & 51 & Height \\
\hline 22 & Judge & 52 & Home state \\
\hline
\end{tabular}


23

24

25

26

27

28

29

30
Lieutenant Governor

Solicitor General

State Representative

State Senator

U.S. President

U.S. Representative

U.S. Secretary

U.S. Senator
53

54

55

56

57

58

59
IQ

Physical attractiveness

Race

Religious affiliation

Surname

Voice

Weight 
Table 2: Bio-index scores of presidential candidates (1896-2008)

$$
\text { (grey= incorrect forecasts) }
$$

\begin{tabular}{|c|c|c|c|c|}
\hline \multirow{2}{*}{$\begin{array}{c}\text { Election } \\
\text { year }\end{array}$} & \multirow{2}{*}{$\begin{array}{c}\text { Winner } \\
(\mathrm{W})\end{array}$} & \multirow{2}{*}{$\begin{array}{c}\text { Loser } \\
(\mathrm{L})\end{array}$} & \multicolumn{2}{|c|}{$\begin{array}{l}\text { Index } \\
\text { score }\end{array}$} \\
\hline & & & $\mathrm{W}$ & $\mathrm{L}$ \\
\hline 1896 & McKinley & Bryan & 19 & 13 \\
\hline 1900 & McKinley & Bryan & 20 & 13 \\
\hline 1904 & Roosevelt & Parker & 23 & 13 \\
\hline 1908 & Taft & Bryan & 21 & 15 \\
\hline 1912 & Wilson & Taft & 27 & 22 \\
\hline 1916 & Wilson & Hughes & 25 & 19 \\
\hline 1920 & Harding & Cox & 19 & 13 \\
\hline 1924 & Coolidge & Davis & 22 & 21 \\
\hline 1928 & Hoover & Smith & 18 & 14 \\
\hline 1932 & Roosevelt & Hoover & 25 & 19 \\
\hline 1936 & Roosevelt & Landon & 23 & 19 \\
\hline 1940 & Roosevelt & Willkie & 22 & 13 \\
\hline 1944 & Roosevelt & Dewey & 22 & 15 \\
\hline 1948 & Truman & Dewey & 20 & 16 \\
\hline 1952 & Eisenhower & Stevenson & 20 & 14 \\
\hline 1956 & Eisenhower & Stevenson & 21 & 14 \\
\hline 1960 & Kennedy & Nixon & 28 & 18 \\
\hline 1964 & Johnson & Goldwater & 24 & 16 \\
\hline 1968 & Nixon & Humphrey & 21 & 15 \\
\hline 1972 & Nixon & McGovern & 23 & 20 \\
\hline
\end{tabular}




$\begin{array}{llccc}1976 & \text { Carter } & \text { Ford } & 21 & 26 \\ 1980 & \text { Reagan } & \text { Carter } & 21 & 20 \\ 1984 & \text { Reagan } & \text { Mondale } & 22 & 17 \\ 1988 & \text { Bush H } & \text { Dukakis } & 27 & 20 \\ 1992 & \text { Clinton } & \text { Bush } & 22 & 24 \\ 1996 & \text { Clinton } & \text { Dole } & 27 & 16 \\ 2000 & \text { Gore* } & \text { Bush } & 23 & 20 \\ 2004 & \text { Bush } & \text { Kerry } & 23 & 21 \\ 2008 & \text { Obama } & \text { McCain } & 25 & 20 \\ & * \text { based on the popular vote } & \end{array}$


Table 3: Hit rate of the bio-index heuristic forecasts (made in January) and benchmark approaches

Benchmark method

Gallup poll

Prediction markets

Econometric Models

Late July / early

Abramowitz (1996)

August

Wlezien \& Erikson

Late August

Early September

Campbell (1996)
Benchmark method

Sample of

Elections

19

26

16

12

.75

.88
15

12

.80

.87

16

13

.81

.88

Note: most accurate forecast in bold 
Table 4: Out-of-sample forecasts of the bio-index model and actual election outcomes (grey: incorrect forecasts)

\begin{tabular}{|c|c|c|c|c|}
\hline \multirow{2}{*}{$\begin{array}{c}\text { Election } \\
\text { year }\end{array}$} & \multicolumn{4}{|c|}{$\begin{array}{c}\text { Incumbent party } \\
\text { candidate's share of two- } \\
\text { party popular vote }\end{array}$} \\
\hline & election & Actual & Predicted & $\mathbf{A E}$ \\
\hline 1896 & 1 & 47.3 & 43.8 & 3.5 \\
\hline 1900 & 0 & 53.2 & 57.4 & 4.3 \\
\hline 1904 & 0 & 60.0 & 59.1 & 0.9 \\
\hline 1908 & 1 & 54.5 & 55.7 & 1.2 \\
\hline 1912 & 0 & 35.6 & 47.8 & 12.2 \\
\hline 1916 & 0 & 51.7 & 54.8 & 3.1 \\
\hline 1920 & 1 & 36.2 & 45.3 & 9.2 \\
\hline 1924 & 0 & 65.2 & 50.5 & 14.7 \\
\hline 1928 & 1 & 58.8 & 54.1 & 4.7 \\
\hline 1932 & 0 & 40.9 & 46.3 & 5.5 \\
\hline 1936 & 0 & 62.5 & 53.0 & 9.5 \\
\hline 1940 & 0 & 55.0 & 59.0 & 4.0 \\
\hline 1944 & 0 & 53.8 & 56.5 & 2.8 \\
\hline 1948 & 0 & 52.4 & 53.9 & 1.5 \\
\hline 1952 & 1 & 44.6 & 44.6 & 0.0 \\
\hline 1956 & 0 & 57.8 & 56.6 & 1.1 \\
\hline 1960 & 1 & 49.9 & 42.1 & 7.8 \\
\hline 1964 & 0 & 61.3 & 56.4 & 5.0 \\
\hline 1968 & 1 & 49.6 & 44.3 & 5.3 \\
\hline 1972 & 0 & 61.8 & 52.2 & 9.6 \\
\hline 1976 & 0 & 48.9 & 53.9 & 4.9 \\
\hline 1980 & 0 & 44.7 & 49.7 & 5.0 \\
\hline 1984 & 0 & 59.2 & 54.2 & 5.0 \\
\hline 1988 & 1 & 53.9 & 55.1 & 1.2 \\
\hline 1992 & 0 & 46.5 & 51.8 & 5.3 \\
\hline
\end{tabular}




$\begin{array}{lcccc}1996 & 0 & 54.7 & 58.9 & 4.2 \\ 2000 & 1 & 50.3 & 52.6 & 2.3 \\ 2004 & 0 & 51.2 & 51.7 & 0.5 \\ 2008 & 1 & 46.3 & 46.7 & 0.4 \\ \text { Sum } & \mathbf{1 0} & - & \text { MAE } & \mathbf{4 . 6}\end{array}$


Table 5: Bio-index model vs. quantitative models: Errors of out-of-sample forecasts (1996-2008, calculated through successive updating)

Forecast error

\section{Approximate date of}

$\begin{array}{lllllll}\text { Model } & \text { forecast } & \mathbf{1 9 9 6} & \mathbf{2 0 0 0} & \mathbf{2 0 0 4} & \mathbf{2 0 0 8} & \text { MAE } \\ & \text { January, or as (potential) } & & & & & \\ \text { Bio-index model } & \text { candidates are known } & 4.3 & 2.4 & \mathbf{0 . 5} & \mathbf{0 . 4} & 1.9\end{array}$

Econometric models

\begin{tabular}{|c|c|c|c|c|c|c|}
\hline Norpoth & January & 2.4 & 4.7 & 3.5 & 3.6 & 3.5 \\
\hline Fair & Late July & 3.5 & 0.5 & 6.3 & 2.2 & 3.1 \\
\hline Abramowitz & Late July / early August & 2.1 & 2.9 & 2.5 & 0.6 & 2.0 \\
\hline Lewis-Beck and Tien & Late August & 0.1 & 5.1 & $1.3^{*}$ & 3.6 & 2.5 \\
\hline Wlezien and Erikson & Late August & 0.2 & 4.9 & 0.5 & 1.5 & 1.8 \\
\hline Holbrook & $\begin{array}{l}\text { Late August / early } \\
\text { September }\end{array}$ & 2.5 & 10.0 & 3.3 & 2.0 & 4.4 \\
\hline Campbell & Early September & 3.4 & 2.5 & 2.6 & $6.4^{*}$ & 3.7 \\
\hline & MAE & & & & & 3.0 \\
\hline
\end{tabular}

Note: most accurate forecasts in bold 
Appendix 1: The variables

\begin{tabular}{|c|c|c|}
\hline 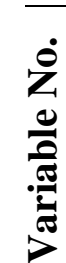 & Variable & Explanations \\
\hline
\end{tabular}

YES / NO VARIABLES

\section{Family}

1 Adopted Has adopted children $\quad$ See children. Voters might favor candidates who adopted children.

children

2 Ancestry Descends from a

Descent from renowned families has been shown to have a positive impact on an individual's presidential family career chances (Simonton, 1984).

3 Children Has children

Being the social norm to have children, voters might favor candidates who have children.

4 Divorce Has not been divorced

Although divorces are common, they violate the social norm.

5 Father Has a father who held a

The role of a candidate's father may have an impact of a candidate's chances to be elected.

(political political office

Similar to Simonton (1981), a score of 1 was assigned if a candidate's father held one of the office) offices listed from questions 18 to 31 .

6 First born Is the first-born child in Simonton (1984) summarizes research showing that first-born children tend to achieve more 


\begin{tabular}{|c|c|c|c|}
\hline 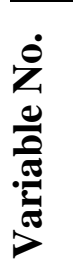 & Variable & $\begin{array}{l}\text { Coded as } 1 \text { if } \\
\text { candidate } \\
\text { (otherwise: } 0 \text { ) }\end{array}$ & Explanations \\
\hline 7 & Single child & Is the single child & $\begin{array}{l}\text { than later-born children. Newman and Taylor (1994) analyze samples of } 45 \text { male U.S. } \\
\text { Governors and } 24 \text { Australian prime ministers. Compared to the population at large, the } \\
\text { politicians in both samples are more likely to be first-born and less likely to be middle-born. } \\
\text { Single children have an advantage over children from larger families. For example, Simonton } \\
\text { (1981) finds a negative correlation between family size and political performance for the } 38 \\
\text { U.S. presidents up to Jimmy Carter. Andeweg and Van Den Berg (2003) analyze birth-order } \\
\text { data for almost 1,200 Dutch politicians. Compared to the general population, they find single } \\
\text { children to be overrepresented, whereas middle-children were underrepresented. }\end{array}$ \\
\hline 8 & Marriage & Is married & It is the social norm to get married. \\
\hline
\end{tabular}

\section{Education}

\begin{tabular}{|c|c|c|c|}
\hline 9 & College & Went to college & Similar to Simonton (1981), the level of formal education is coded by assigning values of 1 , if a \\
\hline 10 & College & Graduated from college & candidate went to college, graduated from college, obtained a Master's degree, obtained a PhD \\
\hline
\end{tabular}




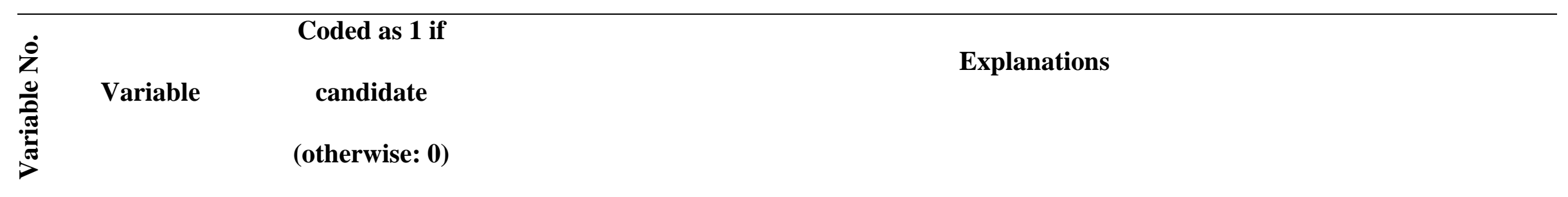

11 Law degree Has a Law (J.D.) degree

12 Master's Has a Master's degree

degree

$13 \mathrm{PhD} \quad$ Has a $\mathrm{PhD} /$ doctoral

degree

14 Professor Has been a college or

university professor

15 Phi beta Is member of Phi beta Similar to Simonton (1981), scholastic performance is measured by quantifying whether a kappa kappa candidate was an in-course (not alumnus or honorary) member of Phi Beta Kappa.

16 Prestigious Attended an Ivy-League college college To have an objective and unambiguous criterion for the reputation of a college, all Ivy-League

17 U.S. Naval / Went to U.S. Naval / colleges as well as the U.S. Naval and Military Academies were considered as prestigious. Military Military Academy 


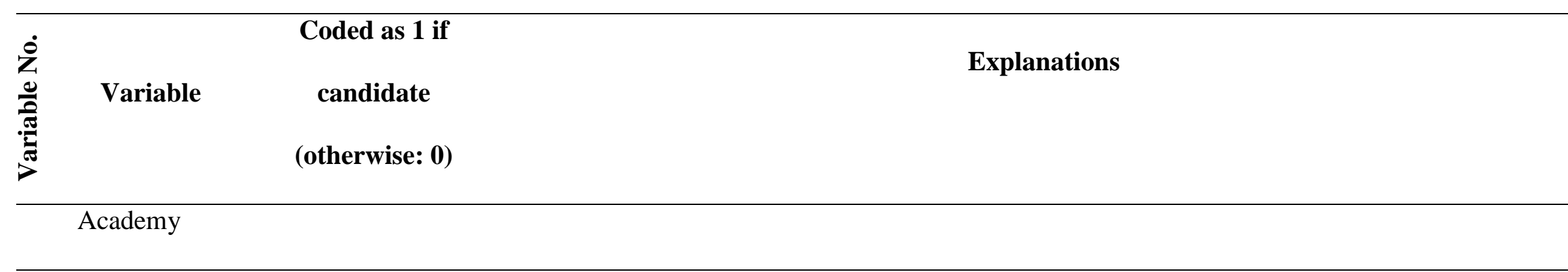

\section{Political life}

\begin{tabular}{lll}
\hline 18 & Attorney & Is / was U.S. or State \\
& General & Attorney General \\
19 & City major & Is / was a city major \\
20 & Election & Has not been defeated in \\
& defeat & a political election $\quad$ Similar to Simonton (1981), prior political experience was assessed by assigning values of 1 if \\
21 & Governor & Is / was a state governor \\
22 & Judge & Is / was a judge \\
23 & Lieutenant & Is / was Lieutenant \\
& Governor & Governor \\
& Solicitor & Is / was U.S. Solicitor \\
& General & General
\end{tabular}




\begin{tabular}{lll}
\hline \multicolumn{2}{c}{$\begin{array}{c}\text { Coded as 1 if } \\
\text { candidate }\end{array}$} & \multicolumn{1}{c}{$\begin{array}{c}\text { Explanations } \\
\text { (otherwise: } 0)\end{array}$} \\
\hline 25 & State & Is / was a state \\
& Representati & representative \\
& ve & \\
26 & State Senator & Is / was a state senator \\
27 & U.S. & Is / was U.S. president \\
& President & \\
28 & U.S. & Is / was a U.S. \\
& Representati & representative \\
& ve & \\
29 & U.S. & Is / was a U.S. Secretary \\
& Secretary & \\
30 & U.S. Senator & Is / was a U.S. senator \\
31 & Vice & Is / was Vice President
\end{tabular}




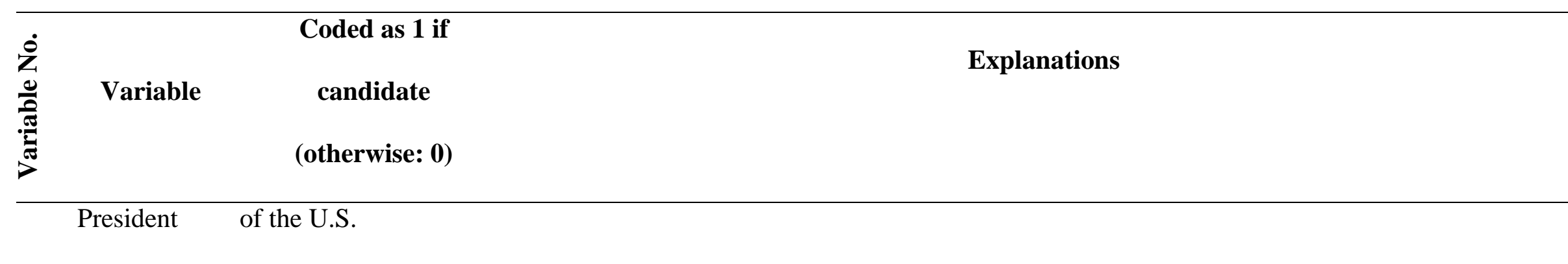

\section{Traumatic / adverse experiences}

32 Disability Suffers from physical or sensory disability

33 Disease Survived a major life-

survivor threatening disease Traumatic experiences that may have a positive impact on leader emergence may be the

34 Chronic Has suffered from survival of a major life-threatening disease, physical or sensory disability, or chronic illness in illness chronic illness in $\quad$ childhood (Simonton 1999, p.115).

childhood or

adolescence (before the

age of 30)

35 Loss of Has lost one or more

Simonton (1999, p.115) reports empirical evidence that supports the idea that the development

children children

of genius may be enforced by traumatic experiences, particularly in childhood or adolescence. 


\begin{tabular}{|c|c|c|c|}
\hline$\frac{\dot{0}}{z_{0}^{0}}$ & Variable & $\begin{array}{l}\text { Coded as } 1 \text { if } \\
\text { candidate } \\
\text { (otherwise: } 0 \text { ) }\end{array}$ & Explanations \\
\hline 36 & $\begin{array}{l}\text { Loss of } \\
\text { sibling }\end{array}$ & $\begin{array}{l}\text { Has lost one or more } \\
\text { siblings }\end{array}$ & $\begin{array}{l}\text { He refers to literature that finds people, who lost a parent during childhood, to be more likely to } \\
\text { achieve more in life. Following Simonton (1981), a candidate is considered an orphan if one (or }\end{array}$ \\
\hline 37 & $\begin{array}{l}\text { Loss of } \\
\text { spouse }\end{array}$ & Has lost a spouse & $\begin{array}{l}\text { both) of his parents died before the age of } 30 \text {. Similarly, scores of } 1 \text { are assigned if a candidate } \\
\text { lost one (or more) children, siblings, or a spouse. }\end{array}$ \\
\hline 38 & Orphanhood & Is an orphan & \\
\hline
\end{tabular}

\section{Other}

39 Age

Is between 47 and 64

Candidates might have a disadvantage if they are either too young or too old. Prior research

years old

supports this assumption for high-level positions in large public firms. In analyzing a sample of

more than 10,000 CEOs, Nelson (2005) finds that the median age was 57 years, the 10th

percentile 47 years, and the 90th percentile 64 years.

40 Athlete Is known as athletic

In his review of the literature, Stogdill (1948) summarizes several studies that found a positive

relationship between leadership and athletic ability.

41 Book author Has authored one or

The number of books that a president published prior to be elected has been found to have a 


\begin{tabular}{|c|c|c|c|}
\hline Z & Variable & $\begin{array}{l}\text { Coded as } 1 \text { if } \\
\text { candidate } \\
\text { (otherwise: } 0 \text { ) }\end{array}$ & Explanations \\
\hline 42 & Celebrity & $\begin{array}{l}\text { Is / was a celebrity in a } \\
\text { field other than politics }\end{array}$ & $\begin{array}{l}\text { positive impact on his political performance (Simonton 1981). In addition, a publishing record } \\
\text { should have a positive impact on the wide recognition of a candidate among voters. } \\
\text { Being a famous person in a field other than politics should have a positive impact on the wide } \\
\text { recognition of a candidate among voters. This can include being a famous actor, athlete, artist, } \\
\text { or TV (radio) moderator. }\end{array}$ \\
\hline 43 & Facial hair & Is clean-shaved & $\begin{array}{l}\text { Several studies examine how facial hair (i.e. clean-shaved, mustache, goateed, beard) } \\
\text { influences perception of people. For example, in their experimental study, Terry and Krantz } \\
\text { (1993) find beards to be associated with lessened competence. Findings from an experiment by } \\
\text { Shannon and Stark (2003) show that the rate of bearded applicants that are selected for } \\
\text { management positions is lower compared to non-bearded applicants. By comparison, results } \\
\text { from an experiment by Reed and Blunk (1990) find consistently more positive perceptions of } \\
\text { social/physical attractiveness, personality, competency, and composure for men with facial } \\
\text { hair. Given that most politicians, especially in recent years (note that William Taft was the last }\end{array}$ \\
\hline
\end{tabular}




\begin{tabular}{|c|c|c|c|}
\hline 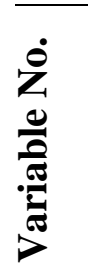 & Variable & $\begin{array}{l}\text { Coded as } 1 \text { if } \\
\text { candidate } \\
\text { (otherwise: } 0 \text { ) }\end{array}$ & Explanations \\
\hline 44 & Glasses & Wears glasses & $\begin{array}{l}\text { U.S. president with facial hair), are clean shaved, facial hair is expected to have a negative } \\
\text { effect on the evaluation of candidates. } \\
\text { In analyzing results from a lab experiment, Thornton (1944) finds people wearing eyeglasses to } \\
\text { be perceived more industrious, dependable, and honest. Another lab experiment finds that } \\
\text { eyeglasses enhance an individual's perceived authority (Bartolini et al.1988). Terry and Krantz } \\
\text { (1993) find eyeglasses to be associated with heightened competence but also diminished } \\
\text { forcefulness. Eyeglasses were expected to have a positive impact on the evaluation of } \\
\text { candidates. }\end{array}$ \\
\hline 45 & Hair & Is not bald & $\begin{array}{l}\text { Although not identifying a voter bias, Sigelman et al. (1990) find that bald and balding men are } \\
\text { underrepresented among governors and Congress members as compared to the general public. }\end{array}$ \\
\hline 46 & $\begin{array}{l}\text { Military } \\
\text { experience }\end{array}$ & Has military experience & $\begin{array}{l}\text { Similar to Simonton (1981), military experience is coded if a candidate served as wartime } \\
\text { recruit, professional soldier, or military general. }\end{array}$ \\
\hline 47 & Military & Has been awarded with & ores of 1 are assigned if a candidate was awarded with military honors. \\
\hline
\end{tabular}




\begin{tabular}{lll}
\hline & $\begin{array}{c}\text { Coded as } 1 \text { if } \\
\text { candidate }\end{array}$ & Explanations \\
\hline honors & military honors & In their meta-analysis, Eagly \& Karau (1991) find men to emerge more often than women as \\
& Is male & leaders from initially leaderless groups. This goes back to the fact that leadership is perceived \\
& & in terms of male stereotypical characteristics, which makes it more difficult for women to \\
& &
\end{tabular}

\section{COMPARATIVE VARIABLES}

49 Facial Is more competent

Several studies measure competence ratings based on people's assessments of candidates'

competence

headshots (Todorov et al., 2005, Antonakis \& Dalgas, 2009). These studies show that

candidates with higher ratings of 'facial competence' are more likely to win elections.

Evaluations of facial competence are available for the 2004 (Little et al., 2007) and 2008

elections (Armstrong et al., 2010).

50 First name

Has the more common

Candidates with the more common first name were expected to have an advantage. Name

first name

popularity was obtained from 1990 U.S. census (http://names.mongabay.com). 


\begin{tabular}{|c|c|c|c|}
\hline 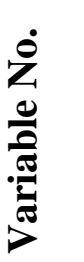 & Variable & $\begin{array}{l}\text { Coded as } 1 \text { if } \\
\text { candidate } \\
\text { (otherwise: } 0 \text { ) }\end{array}$ & Explanations \\
\hline 51 & Height & Is taller & $\begin{array}{l}\text { Height is a well-known predictor for leadership emergence and performance. In their meta- } \\
\text { analysis, Judge \& Cable (2004) find physical height to be positively correlated to esteem } \\
(\mathrm{r}=.41) \text {, leader emergence ( } \mathrm{r}=.24) \text {, performance }(\mathrm{r}=.18) \text {, and income ( } \mathrm{r}=.26) \text {. In estimating } \\
\text { factors to predict presidential greatness, both McCann (1992) and Simonton (1981) find a } \\
\text { positive correlation between height and political performance. }\end{array}$ \\
\hline 52 & Home state & $\begin{array}{l}\text { Is from the state with } \\
\text { more electoral votes }\end{array}$ & $\begin{array}{l}\text { Candidates are likely to win the votes of their home state. Thus, the candidate coming from the } \\
\text { state with more electoral votes was assumed to have an advantage. The numbers for electoral } \\
\text { votes by states in each election were derived from http://www.archives.gov/federal- } \\
\text { register/electoral-college/votes/votes_by_state.html. }\end{array}$ \\
\hline 53 & IQ & Is more intelligent & $\begin{array}{l}\text { Results from a meta-analysis show that intelligence predicts leader emergence (Lord et al., } \\
\text { 1986). Simonton (2006) correlates IQ scores for all } 42 \text { U.S. Presidents before Barack Obama } \\
\text { with evaluations of presidential leadership performance. He found that intelligence is positively } \\
\text { correlated with political success. IQ scores for } 42 \text { presidents were obtained from Simonton }\end{array}$ \\
\hline
\end{tabular}




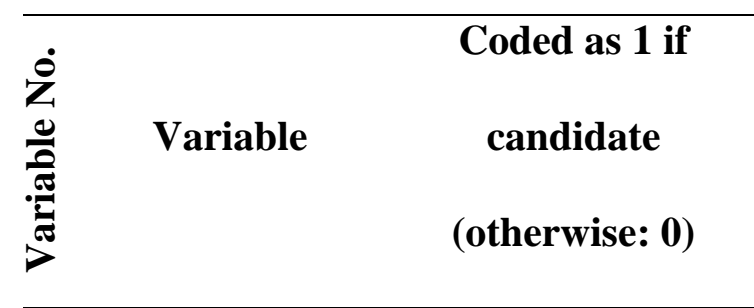

(2006). Where available, information from polls, which ask voters about which candidate appears more intelligent, was used by searching the iPoll Databank of the Roper Center.

54 Physical Is more attractive attractiveness

55 Race

\section{Explanations}

King \& Leigh (2009) assess the beauty of political candidates from major political parties and then estimate the effect of beauty on vote share for candidates in the 2004 Australian election. They find that beautiful candidates are more likely to win elections. Berggren et al. (2010) report a similar effect. In analyzing more than 10,000 visual assessments of almost 2,000 Finnish political candidates, the authors report a positive relationship between attractiveness and the received vote share of candidates. Attractiveness scores for 39 presidents were obtained from Simonton (1986). The coding for the 1920 election race between Harding and Cox is based on Gladwell (2005). Where available, information from polls, which ask voters about which candidate is more attractive, was used by searching the iPoll Databank of the Roper Center.

Voters were expected to more likely endorse a candidate that represents their race. Thus, the 


\begin{tabular}{|c|c|c|c|}
\hline$\frac{\dot{0}}{\frac{0}{0}}$ & Variable & $\begin{array}{l}\text { Coded as } 1 \text { if } \\
\text { candidate } \\
\text { (otherwise: } 0 \text { ) }\end{array}$ & Explanations \\
\hline & & race & $\begin{array}{l}\text { candidate that represents the larger race was expected to have an advantage. Also, in analyzing } \\
\text { ballot photographs for low-information elections, Banducci et al. (2008) find that the } \\
\text { probability of winning for white candidates is } 38 \% \text { greater than for nonwhite candidates. }\end{array}$ \\
\hline 56 & $\begin{array}{l}\text { Religious } \\
\text { affiliation }\end{array}$ & $\begin{array}{l}\text { Is affiliated with the } \\
\text { larger religion }\end{array}$ & $\begin{array}{l}\text { Voters were expected to more likely endorse a candidate that identifies with their religious } \\
\text { beliefs. Thus, the candidate that identifies himself with the larger religion was expected to have } \\
\text { an advantage. }\end{array}$ \\
\hline 57 & Surname & $\begin{array}{l}\text { Has the more common } \\
\text { surname }\end{array}$ & $\begin{array}{l}\text { Candidates with the more common surname were expected to have an advantage. Name } \\
\text { popularity was obtained from } 1990 \text { U.S. census (http://names.mongabay.com). }\end{array}$ \\
\hline 58 & Voice & $\begin{array}{l}\text { Has the more dominant } \\
\text { voice }\end{array}$ & $\begin{array}{l}\text { Gregory \& Gallagher (2002) analyze the acoustic frequency of candidates' voices in } \\
\text { presidential debates. The authors find that this nonverbal vocal communication reveals social } \\
\text { dominance and thus can be helpful to predict the popular vote. This study uses the data from } \\
\text { the eight elections in their sample for our analysis. }\end{array}$ \\
\hline 59 & Weight & Is heavier & In his review of the literature, Stogdill (1948) provides evidence that weight is positively \\
\hline
\end{tabular}




\begin{tabular}{lll}
\hline & Coded as 1 if & \\
\hline & candidate & Explanations \\
\hline & (otherwise: 0$)$ & \\
\hline & correlated with leadership $(\mathrm{r}=.23)$ : seven studies find leaders to be heavier, whereas two \\
& studies find leaders to be lighter; another two studies find no difference. \\
\hline
\end{tabular}




\section{Appendix 2: References for Appendix 1, not cited in the main paper}

Banducci Susan A., Karp Jeffrey A., Thrasher Michael, Rallings Colin. Ballot photographs as cues in low-information elections. Political Psychology 2008; 29(6): 903-917.

Berggren Niclas, Jordahl Henrik, Poutvaara Panu. The looks of a winner: Beauty and electoral success. Journal of Public Economics 2010; 94(1-2): 8-15.

Eagly Alice H., Karau Steven J. Gender and the emergence of leaders: A meta-analysis. Journal of Personality and Social Psychology 1991; 60(5): 685-710.

Gladwell M. Blink: The power of thinking without thinking. London: Little, Brown and Company, 2005.

Gregory Stanford W., Gallagher Timothy J. Spectral analysis of candidates' nonverbal vocal communication: Predicting U.S. Presidential Election outcomes. Social Psychology Quarterly 2002; 65(3): 298-308.

Judge Timothy A., Cable Daniel M. The effect of physical height on workplace success and income: Preliminary test of a theoretical model. Journal of Applied Psychology 2004; 89(3): 428-441.

King Amy, Leigh Andrew. Beautiful politicians. Kyklos 2009; 62(4): 579-593.

Little Anthony C., Burriss Robert P., Jones, Benedict C., Roberts Craig S. Facial appearance affects voting decisions. Evolution and Human Behavior 2007; 28(1): 18-27.

Lord Robert G., de Vader Christy L., Alliger George M. A meta-analysis of the relation between personality traits and leadership perceptions: An application of validity generalization procedures. Journal of Applied Psychology 1986; 71(3): 402-410. 
McCann Stewart J. Alternative formulas to predict the greatness of U.S. presidents:

Personological, situational, and zeitgeist factors. Journal of Personality and Social Psychology 1992; 62(3): 469-479.

Nelson James. Corporate governance practices, CEO characteristics and firm performance. Journal of Corporate Finance 2005; 11(1-2): 197-228.

Reed Ann J., Blunk Elizabeth M. The influence on facial hair on impression formation. Social Behavior and Personality 1990; 18(1): 169-175.

Shannon Micheal L., Stark C. Patrick. The influence of physical appearance on personnel selection. Social Behavior and Personality 2003; 31(6): 613-623.

Sigelman Lee, Dawson Edwin, Nitz Michael, Whicker Marcia L. Hair loss and electability: The bald truth. Journal of Nonverbal Behavior 1990; 14(4): 269-283.

Simonton Dean K. Presidential greatness and performance: Can we predict leadership in the White House? Journal of Personality 1981; 49(3): 306-322.

Simonton DK. Genius, creativity, and leadership. Cambridge, MA: Harvard University Press, 1984.

Simonton Dean K. Presidential personality: biographical use of the Gough Adjective Check List. Journal of Personality and Social Psychology 1986; 51(1): 149-160.

Simonton Dean K. Presidential IQ, openness, intellectual brilliance, and leadership: Estimates and correlations for 42 U.S. chief executives, Political Psychology 2006; 27(4): 511-526.

Stogdill Ralph M. Personal factors associated with leadership: A survey of the literature. Journal of Psychology 1948; 25: 35-71.

Terry Roger L., Krantz John H. Dimensions of trait attributions associated with eyeglasses, men's facial hair, and women's hair length, Journal of Applied Social Psychology 1993; 23(20): 1757-1769. 